Wondimu, P.A., Klakegg, O.J., Lædre, O., and Ballard, G. (2018). "A comparison of competitive dialogue and best value procurement" In: Proc. $26^{\text {th }}$ Annual Conference of the International. Group for Lean Construction (IGLC), González, V.A. (ed.), Chennai, India, pp. 13-22. DOI: doi.org/10.24928/2018/0248. Available at: www.iglc.net.

\title{
A COMPARISON OF COMPETITIVE DIALOGUE AND BEST VALUE PROCUREMENT
}

\author{
Paulos Abebe Wondimu' , Ole Jonny Klakegg ${ }^{2}$, Ola Lædre ${ }^{3}$, and Glenn Ballard ${ }^{4}$
}

\begin{abstract}
Competitive Dialogue (CD) and Best Value Procurement (BVP) are two different approaches to early contractor involvement (ECI) in public projects. However, it is not clear which approach is best suited for what kind of project situations, and which is better for implementing lean in public procurement. The purpose of this paper is to explore the similarities and differences of these approaches to develop recommendations for how to match approach with project situations. In addition to literature study, two large infrastructure projects were studied through 12 in-depth semi-structured interviews and review of documents. The findings from this study indicate that the two approaches have several similarities; e.g., both give a better result when they are used together with a design-build contract than design-bid-build contract, and they give clients possibilities to meet suppliers and clarify projects before contract signing. However, they also have a number of differences such as the number of competitors that develop a project and a supplier selection premises varies. The study concludes that BVP is a moreeffective procurement process than $\mathrm{CD}$ as regards procurement phase. However, CD gives more room for the clients to influence supplier solutions than BVP.
\end{abstract}

\section{KEYWORDS}

Best value procurement (BVP), competitive dialogue (CD), lean, early contractor involvement (ECI), public procurement.

\section{INTRODUCTION}

Main contractors have more experience than clients and designers in construction materials, methods, and local practice. Therefore, they can provide relevant information not only about generic constructability but also about resources availability and

1 PhD Candidate, Department of Civil and Environmental Engineering (DCEE), Norwegian University of Science and Technology (NTNU), Trondheim, Norway/Senior Engineer, Norwegian Public Roads Administration, Norway, +47 90111 814, paulos.wondimu@ntnu.no/ paulos.wondimu@ vegvesen.no

2 Professor, DCEE, NTNU, ole.jonny.klakegg@ntnu.no

3 Associate Professor, DCEE, NTNU,ola.ladre@ntnu.no

4 Professor, DCEE, NTNU/Professor DCEE, University of California Berkeley glenn.ballard@ntnu.no /ballard@ce.berkeley.edu 
limitations in terms of cost, performance, access and site conditions. Construction knowledge and experience is an important element of lean construction. One of the ways to integrate construction knowledge and experience in early phases of a project is early contractor involvement (ECI) (Song et al. 2009). The main goals of ECIare project control, time gains, and innovation(Mosey 2009). ECI can eliminate waste of time, cost and effort that bedevils projects (Walker and Lloyd-Walker 2015). How clients design the procurement procedure decides how well organizations can be integrated and how well the competence may be utilized. The procurement procedure should create room for creative solutions and intensive exchange of ideas. Early start and an interweaving approach are importantin order to create an opportunity for the contractors to play an active role(Lenferink et al. 2012). There are different models of ECI depending on when the contractor gets involved in the project. CD and BVP are two interweaving approaches of ECI that European public owners can use. Both approachesallow interactions between a client and suppliers in early phases of projects and before contract signing (Storteboom et al. 2017; Wondimu et al. 2017).

There is a limited examination of lean thinking in public procurement (Schiele and McCue 2011). There is lack of research in the IGLC community in the area of public procurement, and there is no literature comparing BVP and CD. This paper contributes to addressing this issue byaddressing the following research questions.

- What are the similarity and differences between BVP and CD?

- Which approach is best suited for what kind of project situations?

- Which approach is better to implement lean in public sector projects?

This study has some limitations since the cases are limited to only two Norwegian public road projects.

\section{METHOD}

The research reported in this study includesliterature review and two case studies. The two cases were chosen because they are the first large infrastructure projects in Norway that have used the two approaches. The methodological approaches described by Yin (2014)was used during the case studies.

Literature review formed the basis for the theoretical background. The review of literature was undertaken using IGLC.net conference papers database in addition to the search engines Oria and Google Scholar. Oria is a Norwegian University library resource. Besides, citations chaining according to the principles laid out by Ellis (1993) was also used to find new literature.

The two cases were studied based on 12 in-depth semi-structured interviews with senior professionals from both client and contractor organization. Each interview was carried out face-to-face based on an interview guide and lasted between 60 minutes to 90 minutes. All interviewees were recorded and later transcribed.

A document study was carried out after the literature review and interviews. The document study included tender documents, tender evaluation protocols, and contracts. The purpose of the document study was to supplement the literature review and 
interviews and to achieve data triangulation. The data were hand-coded and analyzed while data were collecting and writing up the findings based on the description of Creswell (2013).

Table 1: Overview of cases and the respective interviewee's position

\begin{tabular}{|c|c|c|c|c|}
\hline $\begin{array}{c}\text { Client/Project } \\
\text { name }\end{array}$ & $\begin{array}{c}\text { Project } \\
\text { Description } \\
\text { (Budget } € \text { ) }\end{array}$ & $\begin{array}{l}\text { Proj. } \\
\text { start- } \\
\text { finish }\end{array}$ & Interviewee's position & $\begin{array}{c}\text { ECl } \\
\text { Approac } \\
\mathbf{h}\end{array}$ \\
\hline $\begin{array}{l}\text { 1) Nye veier/E18 } \\
\text { Rugtvedt-Dørdal }\end{array}$ & $\begin{array}{c}16.5 \mathrm{~km} \text { new } \\
\text { four-lane } \\
\text { highway }(€ 200 \\
\text { mill) }\end{array}$ & $\begin{array}{c}2017 \\
- \\
2019\end{array}$ & $\begin{array}{l}\text { Project director, Assistant project } \\
\text { director, Contract and procurement } \\
\text { director, Construction manager, } \\
\text { Environmental advisor, \& } \\
\text { Construction discipline leader (6 } \\
\text { from the client). }\end{array}$ & BVP \\
\hline $\begin{array}{c}\text { 2) Statens } \\
\text { Vegvesen/E6- } \\
\text { Helgeland North }\end{array}$ & $\begin{array}{l}62 \mathrm{~km} \text { new two- } \\
\text { lane highway } \\
(€ 170 \text { mill })\end{array}$ & $\begin{array}{c}2015 \\
- \\
2019\end{array}$ & $\begin{array}{c}\text { Construction manager, project } \\
\text { manager and a representative } \\
\text { from StatensVegvesenhead office } \\
\text { (3 from the client) \& project } \\
\text { manager, quality manager and } \\
\text { geotechnical engineer ( } 3 \text { from the } \\
\text { contractors) }\end{array}$ & $C D$ \\
\hline
\end{tabular}

\section{THEORETICAL BACKGROUND}

\section{LEAN AND EARLY CONTRACTOR INVOLVEMENT (ECI)}

Based on the Lean Construction Institute recommendation for projects to approach optimality, three elements are required. Those are an integrated organization, aligned commercial interest, and lean management. These elements are also called LCI triangle, see Figure 1. An integrated organization can be interpreted as one in which downstream industry actors participate in upstream activities, and vice-versa. The underlying principle for this side of the LCI triangle is that all relevant competence/knowledge are to be applied simultaneously to the generation, evaluation, and selection of product and process design alternatives. Thisis based on the view that different actors have relevant knowledge, and consequently must be engaged in generating and selecting from alternatives(Ballard 2012).

One of the main goals of ECI is time gains by conducting parallel or interweaving procedures rather than conducting them sequentially (Lenferink et al. 2012). Based on this goal, the authors of this paper consider ECI as one of the means to create an integrated organization and to approach project optimality. Furthermore, based on the authors' interpretation, both CD and BVP cover the first side of the LCI triangle since the purpose of the approaches is to involve contractors in the early phase.

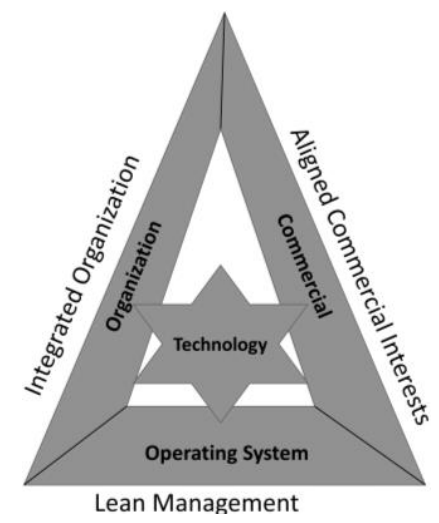


Figure 1: LCI Triangle (Ballard 2012) (driven from Thomsen et al. (2009))

\section{COMPETITIVE DIALOGUE (CD)}

The CD procurement procedure was introduced in 2004 by the European Parliament for particularly complex contracts (European Commission 2006). This procurement procedure allows clients to discussrequirements with short listed suppliers before inviting final written tenders (Uttam and Le Lann Roos 2014). EU public procurement directive describes five circumstances in which the approach canbe used(European Parliament 2014).

It was introduced to provide an improved method for awarding complex public contracts (Arrowsmith and Treumer 2012). It is also intended to give public clients a flexible procurement procedure to enable a dialogue concerning all aspects of the contract with several competitors. The dialogue is an intervening stage between the tender announcement and the submission of final tenders. It is intended to help the client identify and define the means best suited to meeting its objectives. The awarding method in CD procedure is always most economically advantageous tender (MEAT) (Hoezen and Doree 2008). MEAT (price-inclusive multi-criteria selection) is the weighted sum of various aspects of products or service that provides value to the project (Wondimu et al. 2016). Public owners can use CD to stimulate innovation through dialogue(Uttam and Le Lann Roos 2014). CD procedure has five phases; preparation, pre-qualification, dialogue, evaluation \& selection, and execution, see Figure 2.
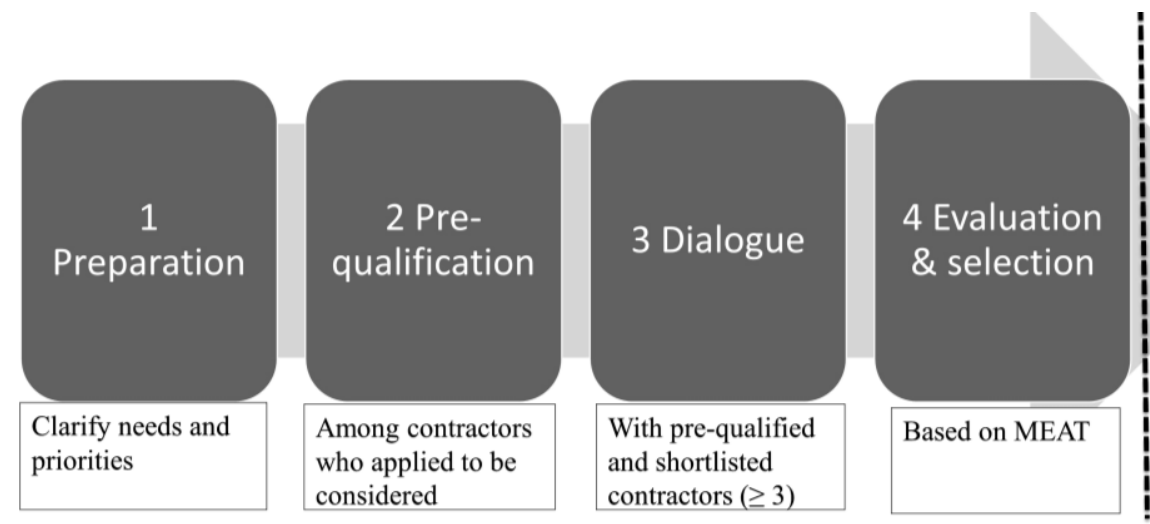

Figure 2: CD phases and majorclient activities

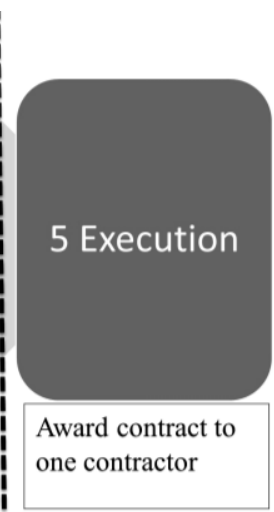

\section{BEST VALUE PROCUREMENT (BVP)}

Best Value Procurement (BVP) BVP is a procurement method that focuses on gaining the best value for the lowest costs (Snippert et al. 2015). A fundamental concept in BVP is the focus on selecting the supplier with the offer that is most advantageous to the client where price and other factors are considered (Elyamany 2010). There are different models of BVP (Perrenoud et al. 2017). This paper explores the BVP model that was introduced by Dean Kashiwagi in 1991 as bestvalue performance information procurement system (BV- PIPS). Regarding BVP there are no EU public procurement laws and regulations that regulate or prohibit from using the approach in public sector. 
This BVP model concentrates on minimizing decision making of clients. One of the fundamental things of this BVP model is that the client should not try to be more expert than the real expert is. The client task is to get the right supplier, and they will deliver the best results. Minimizing the none expert (the client) management, direction, and control of expert suppliers are the philosophy behind BVP. In BVP both price and performance are considered during the selection instead of only price(Kashiwagi 2016).

BVP is an information-based procurement method that predicts theperformance of suppliers based on past performance information. Suppliers are ranked and then selected based on past performance, current capability, price, risk management and the quality of key personnel (Duren et al. 2015).

BVP method has four phases; pre-qualification, selection, clarification, and execution, see Figure 3.

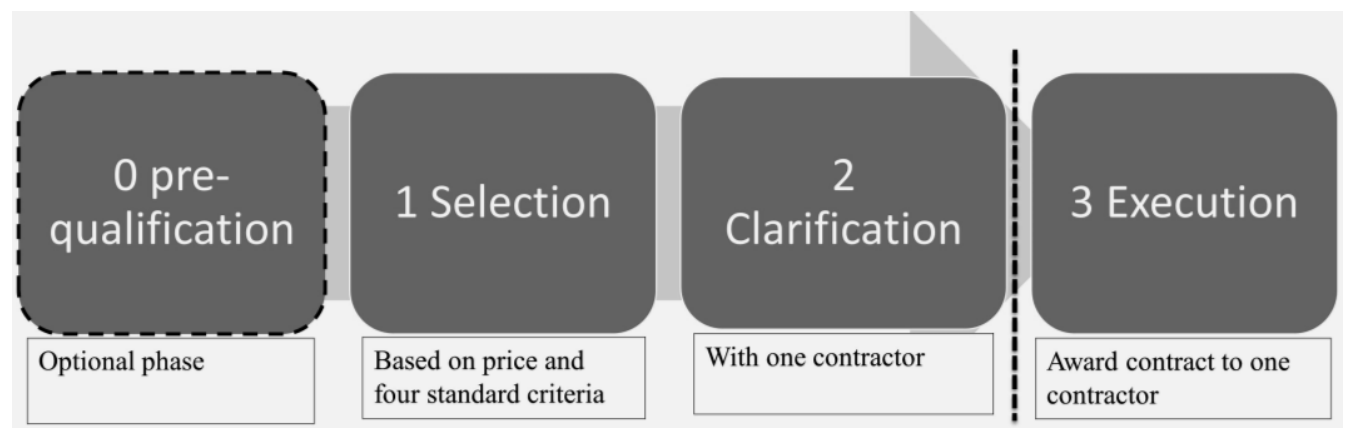

Figure 3: BVP phases and major client activities (developed based on Kashiwagi (2016))

\section{FINDINGS AND DISCUSSION}

\section{COMPARISON OF CD AND BVP}

This section explores the two approaches to determine the similarities and differences between them and to identify which approach suits for what kind of projects. The two case studies through interviews and document study helped to add to the knowledge gain through literature review and to understand how CD and BVP were interpreted in practice. Furthermore, the case studies contributed in determining the comparison factors and facilitate the analysis process.

The two approaches have similarities such as 1) can be used as an approach to implement ECI, 2) can be used under the EU legislation, 3) work best with a design-build contract than design-bid-build contract, and 4) allow interaction between a client and suppliers during the procurement phase before contract award such as during interview, dialogue and clarification. A summary of major differences between the two approaches is presented in Table 2 without recommending one of them over the other. 
Table 2: Comparison between CD and BVP

\begin{tabular}{|c|c|c|c|}
\hline No. & Comparison factors & CD & BVP \\
\hline 1 & Timing of selection & Late selection & Early selection \\
\hline 2 & Pre-qualification & Mandatory & Optional \\
\hline 3 & Interaction & Dialogue & Clarification \\
\hline 4 & $\begin{array}{c}\text { No of competitors develop a } \\
\text { project }\end{array}$ & $\geq 3$ & 1 \\
\hline 5 & $\begin{array}{l}\text { Client's control on the detail } \\
\text { of the supplier's solution } \\
\text { during procurement }\end{array}$ & $\begin{array}{l}\text { High control (The client } \\
\text { knows best - the contractor } \\
\text { is hired to do the job) }\end{array}$ & $\begin{array}{l}\text { Low control (The contractor } \\
\text { knows best - they are } \\
\text { selected because of their } \\
\text { expertise) }\end{array}$ \\
\hline 6 & $\begin{array}{l}\text { Client's role in the selection } \\
\text { of solution }\end{array}$ & $\begin{array}{l}\text { The client can filter the } \\
\text { contractors' solutions in the } \\
\text { dialogue phase }\end{array}$ & $\begin{array}{l}\text { The contractor present their } \\
\text { solution in the clarification } \\
\text { phase }\end{array}$ \\
\hline 7 & $\begin{array}{l}\text { Client's resources need } \\
\text { during the procurement }\end{array}$ & Demanding & Less demanding \\
\hline 8 & $\begin{array}{l}\text { Suppliers resources need } \\
\text { during the procurement }\end{array}$ & $\begin{array}{l}\text { All Shortlisted suppliers are } \\
\text { required to develop } \\
\text { solutions for the project, and } \\
\text { it is demanding for all } \\
\text { suppliers }\end{array}$ & $\begin{array}{l}\text { Only one supplier develop a } \\
\text { solution to a project, and it is } \\
\text { demandingonly for one of the } \\
\text { suppliers }\end{array}$ \\
\hline 9 & Selection criteria & $\begin{array}{c}\text { Technical and varies with } \\
\text { project }\end{array}$ & $\begin{array}{l}\text { Non-technical and } \\
\text { standardized }\end{array}$ \\
\hline 10 & Weightqualification/ price & $\begin{array}{l}10 \% \text { to } 40 \% / \\
90 \% \text { to } 60 \%\end{array}$ & $\begin{array}{l}75 \% / \\
25 \%\end{array}$ \\
\hline 11 & $\begin{array}{l}\text { suppliers compete and } \\
\text { evaluated based on }\end{array}$ & $\begin{array}{c}\text { Project-specific solutions } \\
\text { and price }\end{array}$ & $\begin{array}{c}\text { Four standard criteria and } \\
\text { price }\end{array}$ \\
\hline 12 & Evaluation method/scale & Not standardized & Standardized \\
\hline 13 & $\begin{array}{l}\text { Documents from the } \\
\text { competitors to be evaluated } \\
\text { by the client }\end{array}$ & $\begin{array}{l}\text { Comprehensive } \\
\text { documentation }\end{array}$ & Max 6 pages document \\
\hline 14 & Historical origin & EU & USA \\
\hline 15 & $\begin{array}{l}\text { On what kind of projects } \\
\text { can it be used? }\end{array}$ & $\begin{array}{l}\text { EU public procurement } \\
\text { directive describes five } \\
\text { circumstances in which the } \\
\text { approach canbe used }\end{array}$ & On all kinds of projects \\
\hline 16 & $\begin{array}{l}\text { Client access to suppliers' } \\
\text { idea }\end{array}$ & $\begin{array}{l}\text { The client gets access to } \\
\text { several ideasat a time }\end{array}$ & $\begin{array}{l}\text { The client gets access to only } \\
\text { one idea }\end{array}$ \\
\hline 17 & $\begin{array}{l}\text { In what situation is the } \\
\text { approach suitable }\end{array}$ & $\begin{array}{l}\text { If a client wants to choose a } \\
\text { supplier based on their } \\
\text { solution for a specific project }\end{array}$ & $\begin{array}{l}\text { If a client is looking for an } \\
\text { expert that has done relevant } \\
\text { things several times with high } \\
\text { performance }\end{array}$ \\
\hline
\end{tabular}


The most interesting aspects oftable 2invite some comments:

The first comparison factor is the timing of the selection. In $\mathrm{CD}$, the selection phase is after the dialogue phase. Whereas in BVP the clarification phase that is comparable with dialogue phase in $C D$ is after the selection phase. The purpose of the selection phase in the two approaches differ. In BVP, the purpose is to shortlist andselect the best-qualified contractor to the clarification phase, whereas in $\mathrm{CD}$, the purpose is to award the contract. Furthermore, even if the dialogue phase in $\mathrm{CD}$ and the clarification phase in BVP are comparableregarding the client meeting with suppliers before contract signing, they have a different purpose. The purpose of the clarification phase is a selected supplier explains the scope of the project to the client. That is to clarify what is included and not included in the scope of the project. Whereas the purpose of dialogue phase is to discussall aspects of a project with several pre-qualified and shortlisted suppliers to find, develop or select an optimal solution toa project. The difference means a lot to both clients and suppliers regarding how much resources both contracting parties use in the procurement phase.

In $\mathrm{CD}$, pre-qualification is mandatory before the dialogue phase since the dialogue phase is demanding. In BVP pre-qualification is an optional phase since the whole BVP phases can function as pre-qualification. That means it is possible to use BVP together with open or restricted procurement procedure. Whereas CD should be used together with restricted procedure.

In $\mathrm{CD}$, the interaction between the client and suppliers is dialogue with a purpose of developing an optimal solution for the project. In BVP, the interaction is that the best value supplier clarifies the scope of the project and present a detailed schedule. In CD during the dialogue phase, the suppliers and a client work together to develop an optimal solution for a project. In BVP the supplier that is selectedfor the clarification phase is considered as the expert. Therefore, the supplier is best positioned to clarify the scope.

The next comparison factor is the number of suppliers (competitors) that develop a solution for the project. In CD, at least three suppliers should develop solutions to make sure enough competition, and losers are paid some amount against their cost. This is reasonable since the selection of a supplier is based on their solution to a specific project, and since the selection phase is not over yet. However, in BVP only one supplier should develop a project since the selection phase is already over.

The client control during the procurement is the other comparison factor. In CD, a client selectssuppliers based on their solution to the project. That means the client should know details of the suppliers' solutions during the procurement. Whereas, in BVP a client selectssuppliers based on their past performance. The philosophy behind BVP is to decrease a client's decision-making, management, and control of the expert supplier. All these factors lead to less knowledge and control during the procurement.

The next comparison factor is the resource (time and money) spent by client and suppliers during procurement. In CD, several suppliers develop solutions for a project during the dialogue phase. The client should have a parallelconfidential dialogue with each supplier that is involved in this phase. At the same time, the client should give equal information and treat all suppliers equally to avoid giving acompetitive advantage to anyone. All these factors make CD demanding for the client and for all suppliers that are involved in the dialogue phase. In BVP, only one supplier develops a solution for a 
project during the clarification phase. This makes the procurement phase less demanding for the client and for suppliers that are not selected.

The next comparison factor is the selection criteria. BothCD and BVP use MEAT as a selection method. However, how MEAT is interpreteddiffers in the two approaches. In $\mathrm{CD}$, the MEAT criteria are technical and vary from project to project. Whereas, in BVP the MEAT criteria are non-technical and are the same for all kind of projects. In BVP, the same five criteria (past performance metrics, ability to identify risk, additional value they can provide, capability of their key personnel (interview), and price) should be used in all kinds of projects even if the weighting could vary based on the project's needs.

The length of the documents the suppliers should submit varies in the two approaches. In $\mathrm{CD}$, since the selection of a supplier is based on their solution to a project, they describe their solutions in detail in the form ofcomprehensive documentation. In BVP the suppliers can submit maximum six pages (two pages performance matrix, two pages client's project risk and two pages value adding plan).

European public procurement directives specify five situations when CD may be usedin a project. At least one of the circumstances should be fulfilledin order to use the method. However, regarding BVP there are no public procurement laws and regulations that regulate or prohibit from using the approach in public sector. As long as it is implemented within the existing basicpublic procurement laws and regulations, it is possible to implement the approach in all kinds of projects.

In $\mathrm{CD}$, the client gets access to several suppliers' idea at the same time, the during individualdialogue phase. The selection in this approach is based on the best idea to the project. Therefore, $\mathrm{CD}$ gives the client to select an optimal and innovative solution for the project. In BVP, the client gets access to only one supplier plan to the project during the clarification phase. The selection in this approach is based on best past performance. Only one supplier (the first best value supplier) present their plan to the project during the clarification phase. The client asks questions and comment during this phase if they think their major concerns are not addressed adequately by the plan. If the client manages to document the scope presented by the supplier does not address their major requirements, the client can disqualify the supplier from the clarification phase. Then, they can invite the second best value supplier to the clarification phase to hear their plan.

In sum, one may conclude that CD suits when clients want to choose a supplier based on their solution for a specific project. BVP suits when a client is looking for an expert that has done relevant things several times with high performance.

\section{CONCLUSIONS}

This paper addressed three research questions.

1) What are the similarity and differences between BVP and CD?

The major similarity of BVP and CD is that public owners can use them to implement ECI. Since ECI is one of the important elements of Lean, BVP and CD can be used to implement lean in public sector. The other similarity is that they allow interaction between a client and suppliers before contract signing. Regarding their differences, the major ones are: In CD, several suppliers develop solutions for a project whereas only one 
in BVP. Furthermore, BVP is standardized and effective method compared to CD during the procurement phase.

2) Which approach suits for what kind of project situations?

The selection premises in BVP are based on the suppliers'past performances and ability to understand the current project requirement. Therefore, BVP suits when a client looks for a supplier that has done relevant things several times with high performance. The selection premises in CD arebased on the suppliers' documentation of their solution to a specific project. Therefore, $\mathrm{CD}$ suits when a client is willing to invest more in the procurement phase to increase the product value by competing several suppliers based on their solutions to the project.

3) Which approach is better to implement lean in public sector?

Both BVP and CD can be used to implement lean in public sector. BVP reduce waste and $\mathrm{CD}$ increase value. BVP is an effective procedure during the procurement phase, and it reduces waste in this phase. $\mathrm{CD}$ is relatively an expensive procedure during the procurement phase. However, it facilitates selecting and implementing project solutions that suit the project and the client needs. Therefore, CD increase project value with minor increase of cost during the procurement phase.

This paper contributes to IGLC community by explaining and comparing two methods that can be used by public owners to implement lean during procurement. Future study may explore the potential that the two approaches can from each other achieve both increases in value and reduce waste simultaneously.

\section{REFERENCES}

Arrowsmith, S., and Treumer, S. (2012). Competitive dialogue in EU procurement, Cambridge University Press.

Ballard, G. "Should Project budgets be based on worth or cost." Proc., International conference of the international group for lean construction.

Creswell, J. W. (2013). Research design: Qualitative, quantitative, and mixed methods approaches, Sage publications.

Duren, J. V., Dorée, A., and Voordijk, H. (2015). "Perceptions of success in performance-based procurement: Differences between clients and contractors." Construction innovation, 15(1), 107-128.

Ellis, D. (1993). "Modeling the information-seeking patterns of academic researchers: A grounded theory approach." The Library Quarterly, 63(4), 469-486.

Elyamany, A., and Magdy Abdelrahman (2010). "Contractor performance evaluation for the best value of superpave projects." Journal of Construction Engineering and Management 136(5), 606-614.

European Commission, P. P. P. (2006). "Explanatory Note-Competitive Dialogue-Classic Directive." Directorate General Internal Market and Services.

European Parliament, C. o. t. E. U. (2014). "Directive 2014/24/EU of the European Parliament and of the Council of 26 February 2014 on public procurement and repealing Directive 2004/18/EC Text with EEA relevance." Official journal of the European Union. 
Hoezen, M., and Dorée, A. "First Dutch competitive dialogue projects: a procurement route caught between competition and collaboration." Proc., In 24th Annual ARCOM Conference, Association of Researchers in Construction Management, 535-543.

Kashiwagi, D. (2016). 2016 Best Value Approach, Kashiwagi Solution Model (KSM), USA.

Lenferink, S., Arts, J., Tillema, T., vanValkenburg, M., and Nijsten, R. (2012). "Early Contractor Involvement in Dutch Infrastructure Development: Initial Experiences with Parallel Procedures for Planning and Procurement." Journal of Public Procurement, 12(1), 1-42.

Mosey, D. (2009). Early contractor involvement in building procurement: contracts, partnering and project management, John Wiley \& Sons.

Perrenoud, A., Lines, B. C., Savicky, J., and Sullivan, K. T. (2017). "Using Best-Value Procurement to Measure the Impact of Initial Risk-Management Capability on Qualitative Construction Performance." Journal of Management in Engineering, 33(5), 04017019.

Schiele, J. J., and McCue, C. P. (2011). "Lean thinking and its implications for public procurement: Moving forward with assessment and implementation." Journal of Public Procurement, 11(2), 206.

Snippert, T., Witteveen, W., Boes, H., and Voordijk, H. (2015). "Barriers to realizing a stewardship relation between client and vendor: the Best Value approach." Construction management and economics, 33(7), 569-586.

Song, L., Mohamed, Y., and Abourizk, S. M. (2009). "Early Contractor Involvement in Design and Its Impact on Construction Schedule Performance." J. Manage. Eng., 25(1), 12.

Storteboom, A., Wondimu, P., Lohne, J., and Lædre, O. (2017). "Best Value Procurement - The Practical Approach In The Netherlands." Procedia Computer Science, 121, 398-406.

Thomsen, C., Darrington, J., Dunne, D., and Lichtig, W. (2009). "Managing integrated project delivery." Construction Management Association of America (CMAA), McLean, VA, 105.

Uttam, K., and Le Lann Roos, C. (2014). "Competitive dialogue procedure for sustainable public procurement." Journal of Cleaner Production, 403-4016.

Walker, D. H., and Lloyd-Walker, B. M. (2015). Collaborative project procurement arrangements, PMI.

Wondimu, P. A., Hailemichael, E., Hosseini, A., Lohne, J., Torp, O., and Lædre, O. (2016). "Success factors for early contractor involvement (ECI) in public infrastructure projects." SEB16 Build Green and Renovate Deep, Elsevier`s Energy Procedia, Tallinn and Helsinki.

Wondimu, P. A., Lohne, J., and Lædre, O. (2017). "Motives for the Use of Competitive Dialogue." 25th Annual Conference of the International Group for Lean ConstructionHeraklion, Greece, 53-60.

Yin, R. K. (2014). Case study research: Design and methods, Sage publications. 